\title{
LUCERNE IN NORTH OTAGO
}

\author{
M. G. Elliott and J. C. KeKse
}

M inistry of Agriculture and Fisheries, Oamaru and Balclutha

\section{Abstract}

The increased use and acceptance of lucerne by farmers on the dry North Otago Downlands is described. The typical farmer attitudes, and management barriers, which need to be overcome before further expansion of lucerne areas for grazing purposes, are discussed.

\section{INTRODUCTION}

LUCERNE has proved to be North Otago's most valuable pasture plant under dryland conditions. It is now well accepted in farming with more than 10000 ha on the Downlands, and a further 5000 ha in the Waitaki Plains, Hakataramea Valley, and Omarama districts.

Extension workers have for many years encouraged the growing of more lucerne for hay and grazing. A survey was conducted by J. C. Kerse in 1973 to plan further lucerne extension work and identify research requirements. Thirty-three randomly selected farms on the North Otago Downlands were chosen. Essentially they included the four soil types, Ngapara, Karu, Timaru and Claremont, which comprise the bulk of the Downlands. They are all free-draining, drought-prone soils, ideally suited to lucerne.

The survey was designed to evaluate the farmers' general attitude to growing lucerne, their past experiences, and future expectations, and this paper summarizes the essential findings.

\section{INCREASED AREA AND STOCKING RATES}

A succession of droughts in the 1960s served to highlight the superior production and persistence of lucerne. Farmers on the dry North Otago Downs have recognized the advantages that lucerne offers, and have increased their lucerne area six-fold (3 to $19 \%$ of farm area) in ten years. Intentions are to increase to $34 \%$ by $1978-\mathrm{g}$.

A comparison of lucerne area with stocking rates shows that farms with more lucerne have a higher carrying capacity. Farms with more than $15 \%$ of the total. non-cash-crop 'area in lucerne 
have an average carrying capacity of 1 stock unit/ha higher than those with less than $15 \%$ lucerne.

A small area of lucerne on farms gives an assured feed supply and farmer confidence to increase stock by more than 6 stock units, for each hectare sown in lucerne. With further development to where lucerne is providing the major feed supply, the marginal increases attributed directly to lucerne are less, but 4 to 5 extra stock units for each new hectare of lucerne is typical.

\section{ATTITUDES AND MANAGEMENT BARRIERS}

Attitudes to lucerne vary among farmers. Initial uncertainties with small areas turn to confidence with growing experience.

The surveyed farmers are classified into three groups according to lucerne area. Within each were found typical attitudes and management barriers which need to be overcome before further expansion takes place.

These groups are:

(1) "Fringe users" who are grassland farmers with less than $15 \%$ lucerne..

(2) "Transition farmers", who have begun grazing lucerne, but have less than $30 \%$ lucerne.

(3) "Lucerne farmers" who have greater than $30 \%$ lucerne.

\section{FRINGE USERS}

These farmers have their share of establishment failures, disappointments with short stand life, and poor animal performance with lucerne. Increased dry matter from lucerne is not always readily recognized because much of the feed is conserved as hay, and the long period of lucerne winter dormancy is disappointing compared with ryegrass pastures. They doubt that any benefits could be achieved with more lucerne, and have yet to be convinced of the increased stocking rates and performance that lucerne offers.

They need to learn the basic principles of establishment and elementary husbandries associated with lucerne production.

Where establishment failures occur, the fault usually lies with one or more of the following:

-wrong time of sowing

-lack of moisture

-poor consolidation

-careless drilling 
In the dry climate, sowing must fit a short, critical period in which suitable moisture exists for germination and nodulation. Early planning, thorough cultivation, and careful drilling are essential.

Poor thrift after germination can be due to:

-inoculation failure

-early weed competition

-insufficient lime

-mineral deficiencies

Too often it is not realized that inoculum contains living bacteria, and that these need to stay alive. Reluctance to graze a young stand for weed control can result in weeds becoming dominant. Economizing on lime and overlooking molybdenum at sowing are common failings.

Where established lucerne stands fail to persist the fault usually lies with:

-early and too frequent cutting

-overgrazing

-inadequate topdressing

-poor weed control

Hay and lamb grazing demands made on lucerne are often, too high. Lambs tend to be set-stocked on lucerne after weaning until they are finally drafted. Selective grazing of the growing buds weakens the lucerne. Decline in lucerne thrift can also be associated with inadequate sulphur maintenance dressings and failure to control weeds. Low production requires renewal.

Lucerne establishment is relatively expensive and often leads to prejudice against lucerne. However, if these costs are divided by the average stand life of ten years, they are cheaper than grass pastures which persist for half as long. Healthy stands have lasted for up to twenty years.

By mastering the basic principles of establishment and maintenance these "fringe" users are encouraged to sow more lucerne.

\section{TRANSITION FARMERS}

These farmers have mastered the basics of establishment and are becoming aware that increased dry "matter offers potential for increased carrying capacities. They are all enthusiastic, but need to gain expertise in integrating grass and lucerne grazing. 
Stock welfare still comes first and lucerne is grazed similarly to ryegrass pastures. Lucerne stress is caused by:

-inadequate spelling

-overgrazing

Early spring feed shortages lead to grazing lucerne too early. A common problem is that these farmers have not yet enough lucerne (or lucerne paddocks) to allow good grazing management. Two or three paddock rotations allow insufficient spelling for good lucerne growth. Regrowth in summer consequently suffers. In the dry summer months, lucerne is the only pasture that shows green, so, invariably, farmers succumb to the temptation of putting all their ewes on it. Overgrazing throughout the summer and autumn leaves stands bared when entering winter. This accentuates future early spring feed shortages.

The accumulative effects of these poor management practices weaken the lucerne and favour weeds. Chemical weed control soon becomes essential. This recurring cost is a major complaint amongst these "transition farmers",

Barley grass is the most serious threat to 'lucerne. Infestations occur from:

-buried seed in the paddock

-surrounding fencelines, waste areas, etc.

-weed seed being returned in hay

Suitable chemicals are available, but, unless management attends to both cause and source, reinvasion can be expected and repeat spraying necessary.

This group tends to have more difficulty with stock thrift. When grass paddocks are incorporated into the rotations, a feed adjustment problem becomes apparent. This is overcome by confining sheep to one or the other.

The transition period therefore sees farmers coming to understand the management of lucerne as a plant, and a change in emphasis from grass to lucerne pasture husbandry.

\section{LUCERNE FARMERS}

These farmers have confidence in lucerne as a grazing plant, and plan to increase their area of lucerne further. The impression gained from this group was that "lucerne must be taken seriously". They are well aware of the influence that their management has on lucerne. 
The breeding cycle of flocks has been adjusted to fit more closely to the growth cycle of lucerne. Lambing is later, to coincide with the spring flush of lucerne in September. The bulk of the flock are confined to lucerne all year round. Rotational grazing systems endeavouring to approach the "ideal" have evolved. Advantages of four or five block rotation systems have become apparent, Early weaning of lambs (at 8 or 9 weeks) is possible, ensuring preferential grazing for lambs and this reduces the overall grazing pressure. Surpluses can provide for additional hay and flushing feed.

Innovations which have been successfully introduced are: -establishing with cover crops

-establishing by direct drilling after removal of greenfed with paraquat

-prairie grass/lucerne mixtures

-direct-drilled winter greenfeed into old stands

Problems arise when fitting spring grazing rotations to individual farms. The basic requirements are to sort out suitable four or five block rotations. These may include adjacent lucerne paddocks, or some subdivision may assist. Then, keeping in mind a desired spelling of five to six weeks, one must stock up accordingly as the grazing period approximates 12 to 14 days for four paddock systems, or 9 to 10 days for five paddock systems. Preferences on optimum ewe mob size, and their implications on the number of paddocks or subdivision requirements will be the factors deciding which system and how many rotations are adopted. Internal subdivision needs to be only of a temporary, non-elaborate nature.

With bigger areas of lucerne, the lucerne grazing system becomes easier. Intensively controlled rotational grazing systems can take full advantage of a season of outstanding growth. In such a season, lucerne "gets away", and this favours development of strong plants capable of high future production. With more lucerne, can one preferentially treat establishing stands, or any weakened stand which may have suffered from unavoidable abuse.

These grazing practices, which are aimed at caring for the lucerne plant, are rewarded with increased feed production. This may allow increased animal performance and increasing stocking rates until limitations imposed by the seasonal production of lucerne and the demands of the animal are reached. Further increases in animal production will then depend on skilled transference of feed supplies. 
Flushing feed shortages are overcome by combining: -spring rotational grazing systems -early weaning of lambs

-harvesting spring surpluses as silage or hay, and feeding out prior to flushing

-rape cover crop with lucerne sowing

Winter feed shortages are overcome by -carrying over saved lucerne - silage and hay -direct-drilled cereal greenfeeds -prairie grass/lucerne mixtures -turnip cover crops with sowings -brassica feed crops during lucerne renewal -supplementary cash crop residues

Early spring feed shortages are overcome by: -transference of standing lucerne -direct-drilled greenfeeds -fertility return from a short period of heavy winter mobstocking on old stands -timely chemical weed spraying

With the perfection of these feed transference techniques, the lucerne area can go on increasing until limits imposed by physical -land features, stock health, lucerne pests, and disease, and alternative enterprise preferences are reached.

Traditional limitations to the use of lucerne which are now being overcome are:

(1) Uncultivable contour. Successful oversowing techniques are now possible.

(2) Shady faces. In very dry years superior production over a shortened seasonal and stand life is possible.

(3) Bloat. Some sheep deaths are acceptable as a small cost against increased carrying capacity. Pasture spraying with anti-bloat oils permits cattle grazing.

(4) Barley grass. Overcome by improved chemicals.

(5) Cash cropping. The high spring carrying capacity on lucerne can be very complementary with cash cropping. 
Further research is required for:

(1) New varieties resistant to bacterial wilt and nematodes.

(2) Crown rot diseases.

(3) Investigations of taint flavour in meat from lambs grazing solely on lucerne.

(4) Low sodium level relationships with animal performance.

(5) Factors affecting oestrogenic levels.

(6) Control of red-gut disease.

Provided ways and means of overcoming these apparent problems are found, the already widespread acceptance and use of lucerne will continue to increase with confidence.

The biggest potential for increased livestock production, on the dry North Otago Downs, lies with this increased use and improved production of grazing lucerne. 